\title{
INTERLEUKIN-1 INDUCED GENE EXPRESSION OF NEUTROPHIL ACTIVATING PROTEIN (INTERLEUKIN-8) AND MONOCYTE CHEMOTACTIC PEPTIDE IN HUMAN SYNOVIAL CELLS
}

\section{Deborah DeMarco*, Steven L. Kunkel ${ }^{* *}$, Robert M. Strieter ${ }^{\dagger}$,} Michael Basha ${ }^{\dagger}$, and Robert B. Zurier*1

${ }^{*}$ Rheumatology Section, Department of Medicine, University of Pennsylvania, Philadelphia, PA.

${ }^{* *}$ Department of Pathology and tDepartment

of Internal Medicine, Division of Pulmonary and Critical Care Medicine, University of Michigan Medical School, Ann Arbor, MI 48109

Received November 26, 1990

SUMMARY: We report here that human synovial cells stimulated by interleukin$1 \alpha$ and interleukin-1ß express mRNA for both IL-8 (neutrophil chemotactic peptide) and monocyte chemotactic protein. IL-1 stimulated synovial cells from both osteoarthritis and rheumatoid arthritis patients exhibited similar mRNA expression of interleukin-8 and monocyte chemotactic protein. A capacity to produce factors selectively chemotactic for neutrophils, lymphocytes and monocytes provides a mechanism whereby synovial cells can facilitate inflammatory arthritis. 1991 Academic Press, Inc.

Joint inflammation in rheumatoid arthritis (RA) is characterized by the presence of lymphocytes and monocyte-derived macrophages in a hyperplastic synovium, and polymorphonuclear leucocytes (PMN) in synovial fluid. The reasons why cells invade the synovium and synovial fluid and why synovial cells proliferate in RA patients have not bcen defined. Experimental evidence does indicate that products exported by monocytes, macrophages, lymphocytes and platelets help regulate synovial cell proliferation (1). More recently, factors specifically chemotactic for PMN (neutrophil activating peptide/interleukin-8) or monocytes (monocyte chemotactic protein/MCP) have been identified in several types of cells (2-6). In addition, supernatants from interleukin-1 (IL-1) stimulated human synovial cells in culture express an activity (PMN stimulating factor) that activates neutrophils, as assessed by increased PMN free calcium concentrations

1

To whom correspondence should be addressed.

Abbreviations used: AA, arachidonic acid; DGLA, dihomogamma linolenic acid; EPA, eicosapentaenoic acid; $I L_{-}-1$, interleukin 1 ; IL-8, interleukin 8; MCP, monocyte chemotactic protein; OA, osteoarthritis; PMN, polymorphonuclear leucocytes; RA, rheumatoid arthritis. 
(7). It was therefore of interest to determine whether synovial cells might be able to produce selective chemotactic factors. We report here that human synovial cells stimulated by IL-1 $\alpha$ and IL-1 $\beta$ express mRNA for both IL- 8 and MCP.

\section{MATERIALS AND METHODS}

Synovial Cell Culture: Synovial tissue was obtained with the approval of the Human Experimentation Committee at the University of Pennsylvania, and with the cooperation of the Department of Pathology and Laboratory Medicine, from patients undergoing total knee arthroplasty. Tissue, obtained directly from the operating room to maintain sterility and cell viability, was rinsed with phosphate buffered saline, minced and placed in a trypsinizing flask with $20 \mathrm{ml}$ of $10 \%$ trypsin (Flow Laboratories, McClean, VA) and versene. The flask was kept in a $37^{\circ} \mathrm{C}$ warm room and stirred for $90 \mathrm{~min}$. Supernatant was collected, washed twice in RPMI-1640 (Gibco Laboratories, Grand Island, NY) with $10 \%$ fetal calf serum (FCS) and cells were counted. They were then incubated at a concentration of 1-2 $x$ $10^{6} \mathrm{cells} / \mathrm{ml}$ overnight for adherence. After $24 \mathrm{hr}$, the supernatants were collected and the adherent synovial cells were re-fed with RPMI-20\% FCS. Cultures were allowed to grow to confluence, which usually required 7-10 days, and were then passaged.

Synovial Cell Stimulation; Cells from passage 2-8 were used for all experiments. Cells $\left(0.5-1.0 \times 10^{6} / \mathrm{ml}\right)$ were incubated overnight in $100 \mathrm{~mm}$ culture plates (Costar Cambridge, MA). Supernatants were harvested and adherent cells were washed twice with RPMI without FCS. They were then stimulated with either $5 \mathrm{ng} / \mathrm{ml}$ human recombinant interleukin- $1 \alpha(\mathrm{rhIL}-1 \alpha)$ or $1 \mathrm{ng} / \mathrm{ml}$ interleukin $1-\beta$ (rhIL-1 $\beta$ ) and allowed to incubate at $37^{\circ} \mathrm{C}$ for $8 \mathrm{hr}$. Fatty acids $(10 \mu \mathrm{g} / \mathrm{ml})$ were added to selected cultures. Supernatants were harvested and frozen. Guanidine isothiocyanate ( $3 \mathrm{ml}$ per plate) was added and the mixture frozen until Northern blot analysis for mRNA.

mRNA Assessment: Total cellular RNA was extracted by modifying previously published methods (8). The total RNA extracts were thawed and homogenized. An equal volume of $100 \mathrm{mM}$ tris, (pH 8.0) containing $1.0 \%$ SDS and $10 \mathrm{mM}$ EDTA was added and the RNA extracted with chloroform-phenol. The RNA was separated by formaldehyde/1\% agarose gels and transblotted to nitrocellulose. The baked blots were prehybridized and then hybridized with $32 \mathrm{P}-5$ '-end-labeled 30 -mer oligonucleotide probe. The probes were complementary to either nucleotides 256285 of published cDNA sequence for human monocyte chemotactic activity factor/monocyte chemoattractant protcin or nucleotides 262-291 of a published cDNA sequence for neutrophil chemotactic factor. Blots were stringency washed and autoradiographs were quantified by laser densitometry. Equivalent amounts of total RNA load per gel lines were assessed by monitoring $28 \mathrm{~s}$ and $18 \mathrm{~s}$ rRNA.

\section{RESULTS}

As shown by the Northern blot analysis data in Fig. 1, unstimulated human synovial cells did not constituitively express mRNA for IL-8 (columns A, D, F, I, M). Laser densitometry of the Northern blots demonstrated that significant levels of IL-8 mRNA were induced by small amounts (1400 U) of IL-1 $\alpha$ (columns B, E, G, J) or IL-1ß (column N). 

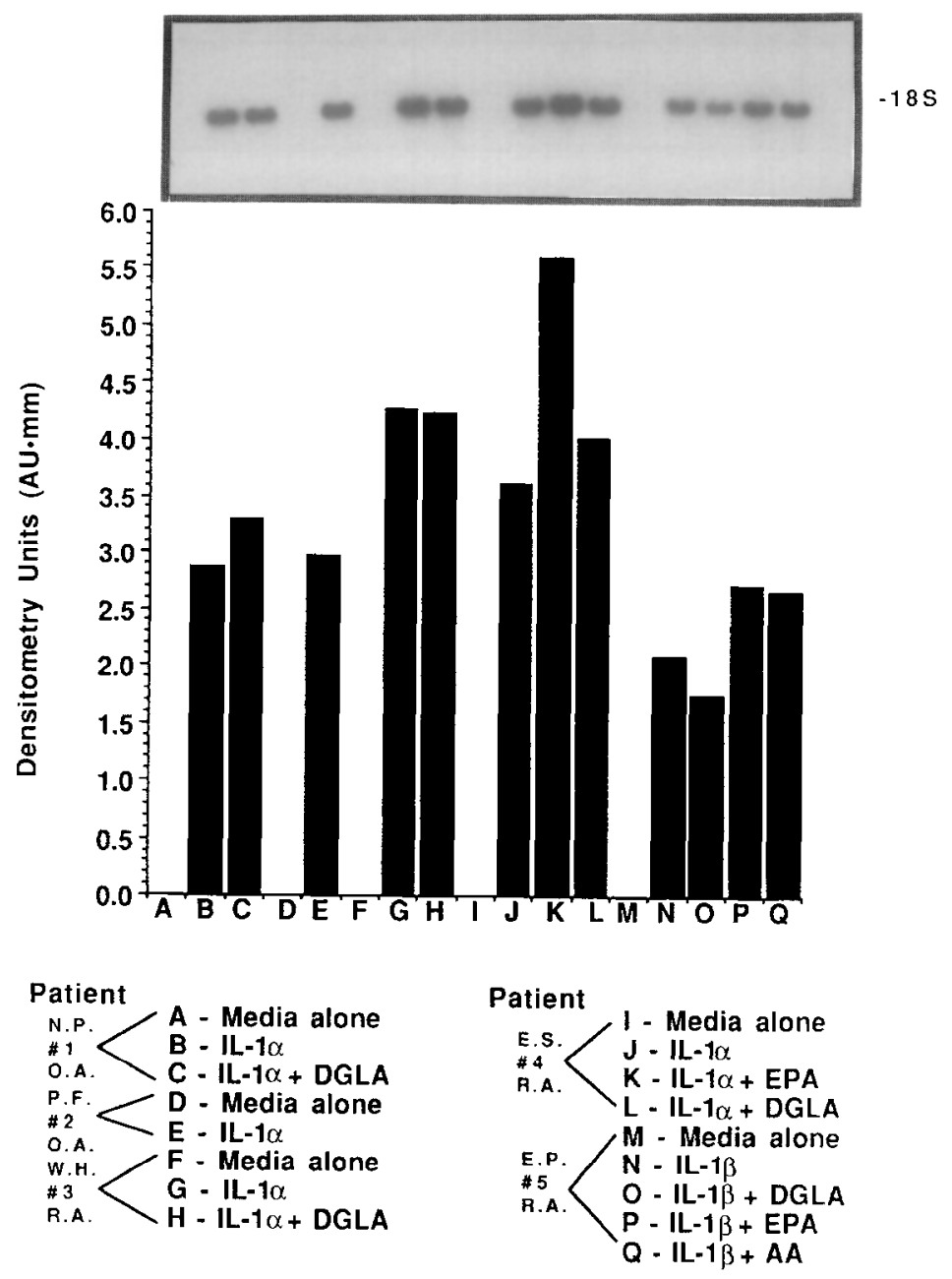

Figure 1. Northern blot analysis of IL- 8 mRNA expression by human synovial cells stimulated with IL-1 $\alpha$ or IL-1B. (Insert, Top). Signals were quantified by laser densitometry of the autoradiographs (bar graph).

OA: Synovium from osteoarthritis patient. RA: Synovium from rheumatoid arthritis patient. DGLA: dihomogammalinolenic acid; AA: arachidonic acid; EPA: eicosapentaenoic acid. Fatty acids $(10 \mu \mathrm{g} / \mathrm{ml})$ added to synovial cells in culture during $8 \mathrm{hr}$ stimulation with IL- $1 \alpha$ or IL- $1 \beta$.

Similarly, human synovial cells do not constituitively express mRNA for MCP (Fig. 2). However, examination of the Northern blot analyses in Fig. 2, indicates that stimulation of these cells with IL-1 $\alpha$ (columns B, E, G, J) or IL-1ß (column N) induces gene expression for MCP (Fig. 2).

Because dihomogamma linolenic acid (DGLA), an unsaturated fatty acid precursor to monooenoic prostaglandins and allied compounds, selectively suppresses growth of IL-1 stimulated human synovial cells in culture (9) and of inflammation and joint tissue injury in animal models (10), we studied its effects on expression of mRNA for IL-8 and MCP. Neither DGLA $(10 \mu \mathrm{g} / \mathrm{ml})$ nor the other prostaglandin precursor fatty acids (arachidonic acid, eicosapentaenoic acid) 

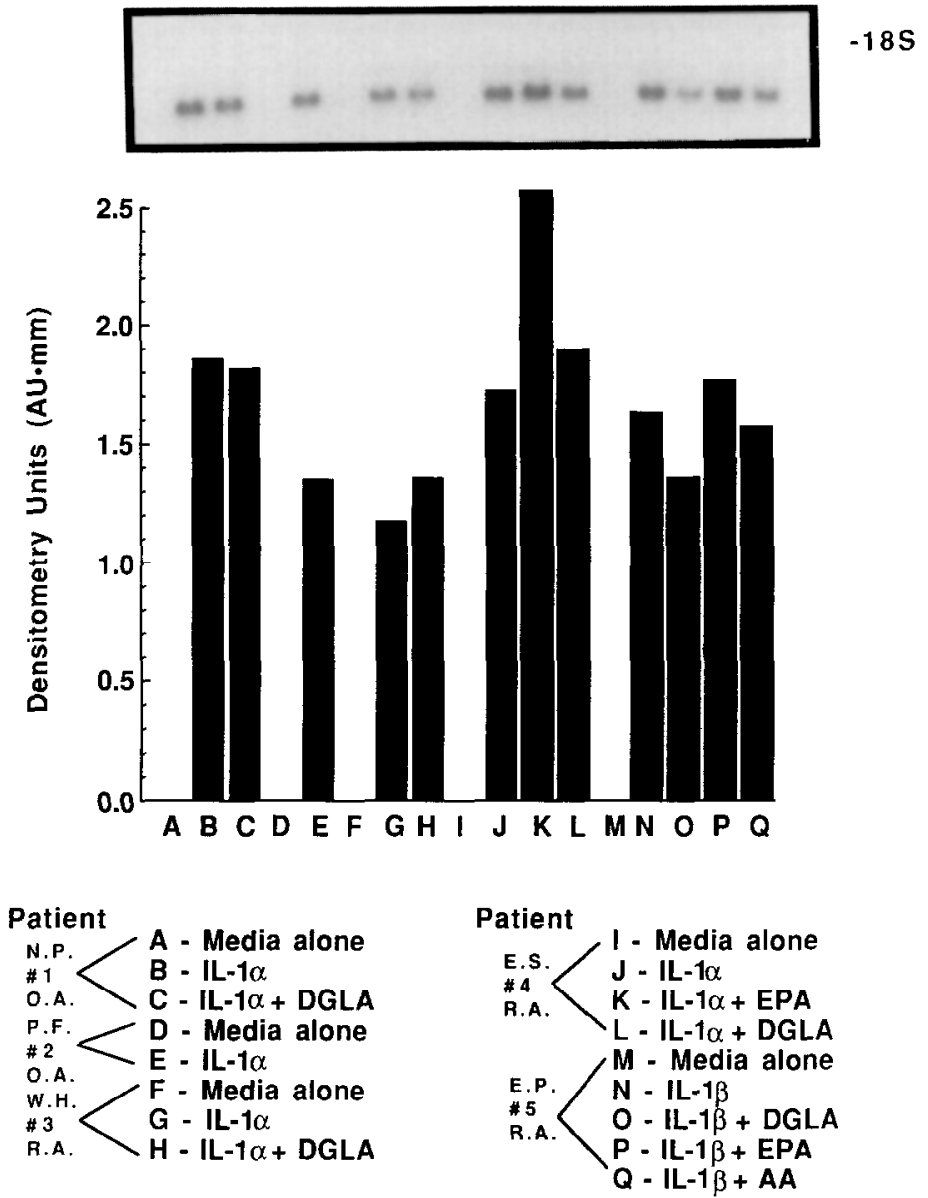

Figure 2. Northern blot analysis of MCP mRNA expression by human synovial cells stimulated with IL-1 $\alpha$ or IL-1B. Abbreviations and methods as in text and in Figure 1.

altered gene expression of IL-8 (Fig. 1, columns C, H, K, L, O, P, Q) or MCP (Fig. 2, same columns).

Quantitative laser densitometry analysis of the Northern blots indicate that IL-1 stimulated synovial cells from both osteoarthritis (OA) and RA patients exhibited similar mRNA expression of IL-8 (Fig. 1) and MCP (Fig. 2). Synovium from the OA patients was hyperplastic and inflamed.

\section{DISCUSSION}

Rheumatoid synovitis likely results from a cellular immune response to an antigen present in synovium or articular cartilage. As a result of a specific immune response, a series of cytokine mediated reactions are set in motion which lead to the mobilization of PMN and of T and B lymphocytes and monocytes whose immunological specificity is largely polyclonal. 
The ability of macrophage derived IL-1 and IL-8 to act as chemotactic agents for lymphocytes $(11,12)$ provides a stimulus for the movement of lymphocytes toward an inflammatory focus. The data presented here indicate that IL-1 has the capacity to stimulate production by synovial cells of IL-8 which could then attract PMN and lymphocytes to the inflamed joint space.

$\mathrm{DR}+$ macrophages are present in rheumatoid synovial tissue. It has been suggested (13) that these cells may represent a specific population, derived from monocytes, that move from the postcapillary venule toward the hyperplastic synovium by virtue of monocyte chemotactic factors released by activated synovial lining cells. The observations presented here that IL-1 does in fact stimulate human synovial cells to express the gene for monocyte chemotactic protein, lends support to this theory.

Streiter et al. found gene expression for individual chemotactic cytokines to be cell and stimulus specific $(4,5)$. Thus, LPS stimulated phagocytic cells (monocytes, PMN, alveolar macrophages), as well as endothelial cells, express mRNA for IL-8 but only LPS stimulated endothelial cells express mRNA for MCP. In contrast, human B lymphocytes treated with LPS fail to express IL-8 mRNA but appear to synthesize a monocyte chemotactic factor in response to LPS. It is therefore of importance that IL-1 stimulated human synovial cells express mRNA for both IL-8 and MCP. The findings emphasize the central role of the synovial lining cells in facilitating development of chronic inflammatory arthritis.

Experimental evidence indicates that selected polyunsaturated fatty acids have antiinflammatory effects. Chief among these is DGLA, which suppresses synovial cell proliferation in vitro (9) and inflammation and joint tissue injury in experimental animal models (10). DGLA also suppresses IL-2 production by stimulated human peripheral blood mononuclear cells (14) and reduces IL-2 driven human T lymphocyte proliferation (15). Preliminary unpublished studies in our laboratory indicate that DGLA administered in vivo or added to cells in vitro reduces TNF production by stimulated human peripheral blood monocytes. Nonetheless, neither DGLA nor other prostaglandin precursor fatty acids (arachidonate and EPA) are able to suppress the expression of IL-8 or MCP 
mRNA, findings which may further define the selectivity of fatty acids in regulation of immune responses.

In the studies presented here, both OA and RA synovial cells express the genes for IL-8 and MCP when stimulated with IL-1. The findings suggest that production of the chemotactic factors is not driven solely by specific antigen. Rather, by this mechanism, synovial cells appear able to amplify an ongoing inflammatory response.

\section{ACKNOWLEDGMENTS}

The work was supported by NIH grants AR38501, HL31693, HL35276 and DK38149, a grant from the Eastern Pennsylvania Chapter, Arthritis Foundation and Award SP57945 from the Commonwealth of Pennsylvania. The authors thank Mrs. Helga Rosenbaum for expert technical assistance and Ms. Esther Lobb for typing the manuscript.

\section{REFERENCES}

1. Zvaifler, N.J., Firestein, G.S. (1988) Scand. J. Rheum. S76:203-210.

2. Walz ,A., Peuiri, P., Aschauer, H., Baggiolini, M. (1987) Biophys. Biochem. Res. Commun. 149:755-761.

3. Furutani, Y., Nomura, H., Notake, M., Oyamada, Y., Fukiu, T., Yamada, M., Larsen, C.G., Oppenheim, J.J., Matsushima, K. (1989) Biophys. Biochem. Res. Commun. 159:249-255.

4. Streiter, RM., Wiggins, R., Phan, S.H., Wharran, B.L., Showell, H.J., Remick, D.G., Chensue, S.W., Kunkel, S.L. (1989) Biophys. Biochem. Res. Commun. 162:694-700.

5. Streiter, R.M., Chensue, S.W., Standiiford, T.J., Basha, M.A., Showell, H.J., Kunkel, S.L. (1990) Biophys. Biochem. Res. Commun. 166:886-891.

6. Thornton, A.J., Strieter, R.M., Lindley, I., Baggiolini, M., Kunkel, S.L. (1990) J. Immunol. 144:2609-2613.

7. Watson, M.L., Westwick, J., Fincham, N.J., Camp, R.D. (1988) Biochem. Biophys. Res. Commun. 155:1154-1160.

8. Jonas, E., Sargent, T.D., David, I.B. (1985) Proc. Natl. Acad. Sci. USA 82:54135417.

9. Baker, D.G., Krakauer, K.A., Tate, G., Laposata, M., Zurier, R.B. (1989) Arthritis Rheum 32:1273-1281.

10. Tate, G., Mandell, B.F., Laposata, M., Ohliger, D., Baker, D.G., Schumacher, H.R., Zurier, R.B. (1989) J. Rheumatol. 16:729-733.

11. Miossec, P., Yu, C.L., Ziff, M. (1984) J. Immunol. 133:2007-2011.

12. Larsen, C.G., Anderson, A.O., Apella, E., Oppenheim, J.J., Matsushima, K. (1989) Science 243:1464-1466.

13. Ziff, M. (1990) J. Rheumatol. 17:127-133.

14. Santoli, D.S., Zurier, R.B. (1989) J. Immunol. 143:1303-1309.

15. Santoli, D., Phillips, P.D., Colt, T.L., Zurier, R.B. (1990) J.Clin. Invest. 85:424-432. 